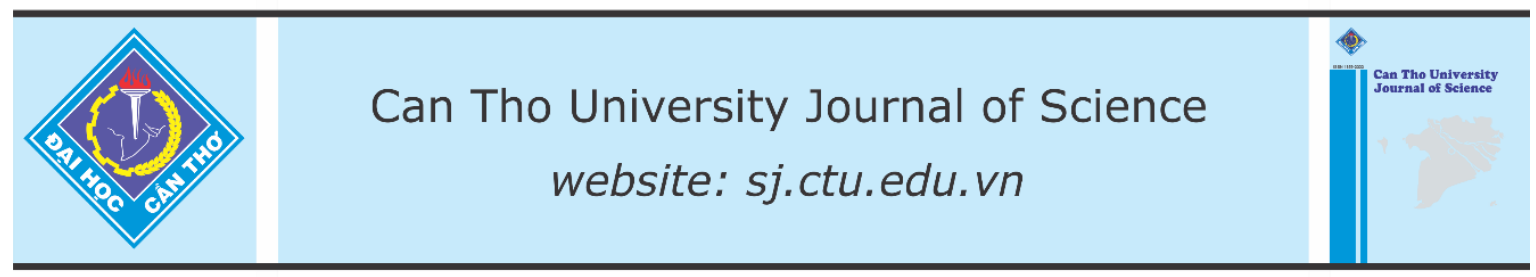

DOI: 10.22144/ctu.jen.2021.017

\title{
The effect of guava (Psidium guajava) leaf extract on the quality of cobia (Rachycentron canadum) fillets during ice storage
}

\author{
Tran Minh Phu ${ }^{1 *}$, Huynh Thi Kim Duyen ${ }^{1}$, Nguyen Le Anh Dao ${ }^{1}$, Nguyen Thi Nhu Ha ${ }^{1}$, \\ Nguyen Quoc Thinh ${ }^{1}$ and Tomoaki Hagiwara ${ }^{2}$ \\ ${ }^{I}$ Department of Seafood Science and Technology, College of Aquaculture and Fisheries, Can Tho \\ University, Viet Nam \\ ${ }^{2}$ Department of Food Science and Technology, Tokyo University of Marine Science and Technology, Japan \\ *Correspondence: Tran Minh Phu (email: tmphu@ctu.edu.vn)
}

\section{Article info.}

Received 22 Feb 2021

Revised 08 May 2021

Accepted 04 Jun 2021

\section{Keywords}

Dip treatments, ice storage, Psidium guajava quality, Rachycentron canadum

\section{ABSTRACT}

The aim of this study is to evaluate the effects of Psidium guajava leaves extract on the quality of cobia (Rachycentron canadum) fillets during in ice storage. A group of cobia fillets was soaked in Psidium guajava extract solutions at concentration of $0.03 \%(w / v)$ for 30 minutes while the other group soaked in cold ice water, considered as control treatment. The experimental fillets were packed and stored in ice for 15 days. Sampling were done on the $1^{\text {st }}, 5^{\text {th }}, 10^{\text {th }}$ and $15^{\text {th }}$ day. Analyzed parameters included temperature, total viable counts (TVC), sensory property, $\mathrm{pH}$, moisture, water holding capacity $(W H C)$, texture, total volatile base nitrogen $(T V B-N)$, peroxide value $(P V)$, Thiobarbituric acid reactive substances (TBARs), and fillet color. The results indicated that cobia fillets treated with guava extract solutions $0.03 \%$ showed significantly higher sensory property, lower PV and TBARs compared to the control treatment during ice storage. Based on the sensory property and total viable counts, cobia fillets can be used up to 10 days in both treatments remaining high quality of the cobia fillet.

\section{INTRODUCTION}

Cobia (Rachycentron canadum) become a potential aquaculture species due to the fast growth, low mortality, and high valuable marine fish in the market. According to Vietnam Association of Seafood Exporters and Producers (VASEP, 2018), the total cobia production in Vietnam was estimated as of 5,500 tons. Cobia was reared around islands along the coastal of Vietnam. Fingerlings were stocked in cages and reared for over a year to reach the commercial size from 5 to $7 \mathrm{~kg}$. Fish were fed mainly by trash-fish (Khanh et al., 2017). Cobia contains high lipid level in fish muscle, mainly polyunsaturated fatty acids. Consumption fish containing high amount of polyunsaturated fatty acids could reduce the risk of heart disease (Vanschoonbeek et al., 2003), increase ability of brain cell formation in children, contribute to eye function, and enhance the immunity (Innis, 1991). However, the high lipid content in cobia flesh may lead to lipid oxidation during storage and processing which become one of the main causes of spoilage, formation of odorous compounds, and potentially harmful substances (Babovic et al., 2010). Lipid oxidation decreases the quality of food, changes color, taste, structure muscle and forms compounds harmful for health (Kanner, 1994). 
The spoilage of fish during storage is usually caused by the microbial growth and enzymatic activities, protein degradation and lipid oxidation resulted in short shelf life and reduced flesh quality (Arashisara et al., 2004). Cobia sticks remained safe and with good microbiological, physical and chemical quality for a 28 days at $5{ }^{\circ} \mathrm{C}$ in a modified atmosphere MAP $\left(15 \% \mathrm{~N}_{2}+80 \% \mathrm{CO}_{2}+5 \% \mathrm{O}_{2}\right)$ (Gonçalves \& Santos, 2018). A shelf-life of 15 days was defined for raw cobia stored on ice (Fogaça et al., 2017). Cobia steaks held in cold store $\left(-18^{\circ} \mathrm{C}\right)$ for more than 5 months (Robinson et al., 2012) while cobia fillet can be stored more than 6 months without reduction of flesh quality (Baldi et al., 2018). Taheri and Motallebi (2012) indicated that vacuum packaging was effective in reduce lipid oxidation and increased shelf life of Cobia frozen fillets. Taheri et al. (2012) revealed that ascorbic acid $0.5 \%$ retarded oxidative changes in frozen cobia fillets.

Preservation of the fish product by using additives or processing technology application become necessary to prolong the fish shelf life and remain the quality. Among natural products using as additives, plant extracts are good candidates as potential successful means to extend the shelf life of seafood (Erkan et al., 2011; Falguera et al., 2011). Many plants or herbals are proven to possess antioxidants and antimicrobials properties. They are applied to treat fish before storage to improve the quality and to maintain shelf life of fish products (Fan et al., 2008; Tehari et al., 2012; Feng et al., 2012; Li et al., 2012). P. guajava has shown biological activities such as antioxidant, antibacterial, antifungal and anticancer (Chen \& Yen, 2007; Metwally et al., 2010). However, little work has been conducted on the effects of $P$. guajava extract to quality of seafood. Therefore, this study was conducted to evaluate the influence of $P$. guajava extract on changes of cobia fillets quality during iced storage through changes of biological, chemical indicators.

\section{METHODOLOGY}

\subsection{Research materials}

Cobia were reared from sea cage in Nam Du Island, Kien Giang Province and slaughtered in July 2018. At the start of experiment, Cobia (16 fish; 4 females; 4-6 kg/fish) was harvested by a sweep net. Fish were killed in ice for 5 minutes in square plastic container $(1,000 \mathrm{~L})$. Fish were bled for 10 minutes, then removed scale manually. Fish was filleted pre rigor with individually labelled fillets $(954 \pm 167 \mathrm{~g} /$ fillet $)$. After that, fillets were soaked with $P$. guajava solution in cages in Nam Du Island before ice storage and transport to College of Aquaculture and Fisheries, Can Tho University.

The $P$. guajava leaves were collected from various areas in the Mekong Delta, Vietnam. The driedpowder $(100 \mathrm{~g})$ was soaked in ethanol $96 \%$ (800 $\mathrm{mL}$ ) for at least 24 hours at room temperature with frequent agitation. The solvent-containing extracts were then decanted and filtered. The ground samples were further extracted 4 times with ethanol $96 \%$. The filtrates from each extraction were combined and the solvent was evaporated under reduced pressure using a rotary evaporator to give crude ethanolic extracts. All extracted samples were lyophilized until dryness and stored at $-20^{\circ} \mathrm{C}$ before use. The concentration of $P$. guajava extract selected in this experiment is based on a minimum inhibitory concentration (MIC) of $0.03 \%$ obtained from Le Anh Dao et al. (2020).

\subsection{Research methods}

\subsubsection{Experimental design}

In this study, 32 cobia fillets from 4 females and 12 males were randomly assigned into two treatments such as soaking in ice tap water (control), in solution of $0.03 \%$ of $P$. guajava ethanolic extract $(P$. guajava soaking treatment). Soaking solutions were maintained below $4^{\circ} \mathrm{C}$ by adding ice and soaking time was 30 minutes. Ratio of fish weight and solution was 1:1 (w:v). After soaking, fillets were drained for 5 minutes before packing in sterile polyethylene bags (1 fillet per bag). Fillets were then placed into insulated box $(100 \mathrm{~L})$ with fish and ice ratio of 1:1 (w:w). Fish were transported to College of Aquaculture and Fisheries, Can Tho University. During storage, ice was added and water inside the box was removed every day. The day of slaughter is considered as day 0 .

Sampling was taken on the $1^{\text {th }}, 5^{\text {th }}, 10^{\text {th }}$, and $15^{\text {th }}$ days of ice storage. At each sampling time and for each treatment, four fillets were collected including three male fillets and one female fillet. Each of fillets were used for sampling of total viable counts (TVC), the top parts of fish fillets were used to measure the texture property and color, the middle parts of fish fillets were used for sensory analysis and the remaining of fillets were minced individually for measurement of $\mathrm{pH}$, moisture, water holding capacity (WHC), total volatile base nitrogen (TVB-N), peroxide value (PV) and Thiobarbituric acid reactive substances $\left(\mathrm{TBAR}_{\mathrm{S}}\right)$. 


\subsubsection{Analytical methods}

\section{Temperature}

On the days of sampling, fillet temperature $\left({ }^{\circ} \mathrm{C}\right)$ was measured in four fillets in each treatment, by thermometer (Ebro, Germany).

\section{pH}

The $\mathrm{pH}$ was determined in duplicate in a 1:1 (w:v) mixture of minced muscle and $0.15 \mathrm{M} \mathrm{KCl}$ by a digital pH meter (C1020, Consort, Germany) equipped with a combined glass-electrode, according to method described in Hultmann et al. (2012).

\section{Moisture content}

The moisture content was determined by drying minced muscle (in quadruplicate) at $105^{\circ} \mathrm{C}$ until constant weight.

\section{Sensory property}

The sensory quality of cobia fillets was evaluated using the quality index method (QIM) by a panel of seven trained members (Sveinsdottir et al., 2003). QIM is based on significant, well-defined changes of appearance attributes that occur in raw fish after storage, such as odor, texture, color, gaping and surface. A score from 0 to 3 demerit points was given for 5 quality parameters according to specific parameter descriptions (Table 1). A value of 0 corresponded to very fresh fillets. The scores increased according to spoilage with a maximum score of 3 for each parameter. The 5 scores are summed to give an overall sensory score referred to as the Quality Index (QI) which can vary from 0 (very fresh) to a maximum 14 score (very bad).

Sensory evaluation of cooked cobia fillets in term of taste was conducted according to Simeonidou
(1997). A trained sensory panel of seven persons analyzed the samples and classified property on a scale from 1 to 9 where 1 is no intensity and 9 is clear intensity. A sensory score of 5 was taken as the threshold of acceptability (Table 2). Four parts of fillets from each group were used for sensory analysis. Each evaluator received one sample from each of the fillets. The fillets were kept in ice until the sensory analysis. On the day of analysis, the fillets, without skin and bones, were cut in $4-5 \mathrm{~cm}$ and heated with steam from boiling water in an oven and served to the evaluators in randomized order at the time of testing.

Table 1. Description and explanation of the properties in sensory analysis

\begin{tabular}{lll}
\hline $\begin{array}{l}\text { Quality pa- } \\
\text { rameters }\end{array}$ & Description & Score \\
\hline \multirow{4}{*}{ Texture } & Firm and elastic & 0 \\
& Somewhat soft & 1 \\
& Soft & 2 \\
& Very soft & 3 \\
\hline \multirow{3}{*}{ Surface } & Very shiny & 0 \\
& Rather wrinkled and dried & 1 \\
& Wrinkled, dried & 2 \\
\hline \multirow{4}{*}{ Odor } & Fresh, seaweed & 0 \\
& Neutral, slightly fishy & 1 \\
& Fishy & 2 \\
& Sour, ammonia smell & 3 \\
\hline \multirow{4}{*}{ Color } & Cloudy white, bright & 0 \\
& Pinkish & 1 \\
& Yellowish & 2 \\
\hline \multirow{3}{*}{ Gaping } & Overall pink or yellow & 3 \\
\hline Quality index (0-14) & 0 \\
\hline
\end{tabular}

Table 2. Sensory evaluation of cooked cobia fillets

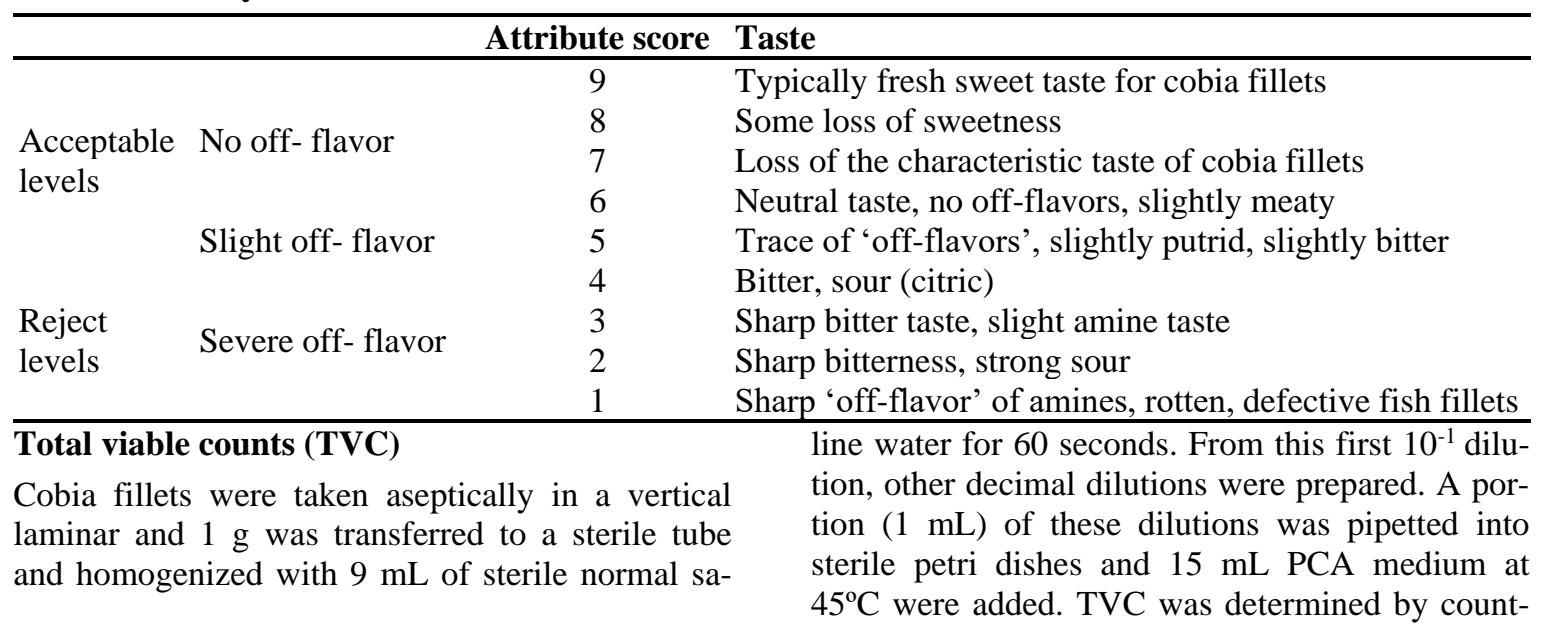


ing the number of colony-forming units after incubation at $30^{\circ} \mathrm{C}$ for 48 hours. Petri dishes containing from 25 to 250 colonies were selected for the counting according to Nordic Committee for Food Analyses (NMKL 86, 2006).

\section{Texture analysis}

The texture profile analysis (TPA) of fillets were performed using a texture analyzer (Model TA.XTplus Texture Analyzer, Stable Micro Systems, Godalming, UK). The conditions of the texture analyzer were as follows: pretest speed, 1.0 $\mathrm{mm} / \mathrm{s}$; posttest speed, $10.0 \mathrm{~mm} / \mathrm{s}$; distance, 5.0 $\mathrm{mm}$; trigger type, auto; and trigger force, $5 \mathrm{~g}$. The calculation of TPA values was obtained by graphing a curve using force and distance. Penetration values (peak force of the compression cycle) of fish fillets were measured by using a $\mathrm{P} / 5 \mathrm{~S}$ probe (5 $\mathrm{mm}$ spherical stainless, Stable Micro Systems).

\section{Water holding capacity (WHC)}

WHC was determined in each fish using the centrifugation method described by Ofstad et al. (1993). Minced muscle (1.5 g) was put in a $15 \mathrm{~mL}$ centrifugal tube and centrifuged at $4^{\circ} \mathrm{C}$ for 10 minutes at $300 \mathrm{~g}$ (using a Mikro 22-R centrifuge (Hettich zentrifugen, Germany)). WHC is given as fraction of water bound after centrifugation ( $\%$ of total water). The analyses were run in quadruplicate.

\section{Total volatile base nitrogen (TVB-N)}

TVB-N was measured following the method described by Velho (2001). Five grams of fish sample were loaded into a Kjeldahl tube, followed by $2 \mathrm{~g}$ $\mathrm{MgO}$ and $50 \mathrm{~mL}$ distilled water. This tube was then agitated and placed in the Kjeldahl distillation system. The distillation was performed for 5 minutes, and then the distillate was collected in a flask containing $25 \mathrm{~mL}$ boric acid $1 \%$ (mixed indicator of methyl red/methylene blue 2:1). Afterward, the boric acid solution was titrated with a $0.1 \mathrm{~N}$ sulfuric acid solution.

\section{Color measurements}

Fish samples are measured color at a fixed position in the middle of the piece fish, $10 \mathrm{~cm}$ from the head of the fish, using the equipment Spectrophotometer (C160) according to principle of CIE Lab system $\left(L^{*} a^{*} b^{*}\right)$ with $L^{*}$ indicated the lightness within the scale range of $0-100$ points from black to white, $a^{*}$ indicated the position between red $(+)$ and green $(-)$, and $b^{*}$ indicated the position between yellow (+) and blue (-). Each treatment was repeated 3 times (Pathare et al., 2013). The values were recorded as $L *, a *, b *$.

\section{Peroxide value $(\mathbf{P V})$}

Peroxide values were determined according to the spectrophotometric ferric thiocyanate method of International IDF Standards (2006). Fish samples $(5 \mathrm{~g})$ were extracted by $20 \mathrm{~mL}$ of chloroform: methanol mixture (2:1) (v:v). After shaken for 3 hours, solution was centrifuged at $700 \mathrm{~g}$ at $25^{\circ} \mathrm{C}$ for 5 minutes. The lower phase was collected for determination of fat content and considered as the sample extract for the latter analysis. The sample extract $(1 \mathrm{~mL})$ was mixed with $3.9 \mathrm{~mL}$ chloroform: methanol (2:1). Then, $50 \mu \mathrm{L}$ of $\mathrm{Fe}^{2+}$ solution $(0.018 \mathrm{M})$ was added and later on with $50 \mu \mathrm{L}$ $\mathrm{NH}_{4} \mathrm{SCN} 30 \%$. The solution was stirred on a vortex mixer for 15 seconds. The absorbance of the sample was measured at $480 \mathrm{~nm}$ against a blank that contained all the reagents except the sample. Peroxide values, expressed as milliequivalents $(\mathrm{mEq})$ peroxide $/ \mathrm{kg}$ fish fat, were calculated based on the concentration of $\mathrm{Fe}^{3+}$ determined from regression line $(y=a x+b)$ and the fat content of fish samples.

\section{Thiobarbituric acid reactive substances (TBARS)}

TBARS were determined according to the spectrophotometric method of Raharjo et al. (1992). Fish sample was homogenized and extracted duplicated in TCA $5 \%$. After centrifugation at $1,050 \mathrm{~g}$ for 15 minutes at $4^{\circ} \mathrm{C}$, the supernatant was collected and filled up to $50.0 \mathrm{~mL}$ in volumetric flask. In the test tubes, $2.0 \mathrm{~mL}$ of extracted sample and TEP standard solution was added, following with addition of $2.0 \mathrm{~mL}$ of TBA reagent $80 \mathrm{mM}$. The solution was stirred on a vortex mixer for $15 \mathrm{~s}$ and placed in a water bath at $94^{\circ} \mathrm{C}$ for 5 minutes. Samples will be cooled in a cold-water bath and measured the absorbance with the spectrophotometer at $530 \mathrm{~nm}$.

\subsection{Statistical analysis}

All data were expressed as mean \pm standard deviation by Microsoft Excel. The data of all parameters analyzed at each sampling time were subjected to analysis of variances (t-Test: Two-sample Assuming Unequal Variances) using SPSS 16.0. Differences at $\mathrm{p}<0.05$ were considered significant.

\section{RESULTS AND DISCUSSION}

\subsection{Temperature}

The core temperature of fillets assembled during ice storage was below $4^{\circ} \mathrm{C}$, ranged from 0.7 to 
$\left.1.38^{\circ} \mathrm{C}\right)$. There was no significant difference between fillets temperature at each sampling day ( $>>0.05$ ). Icing is one of the most prevalent technique for fresh fish preservation (Roberts et al., 2005). Thus, fillet stored in ice in this experiment satisfied the requirements of the cryopreservation.

\subsection{Muscle $\mathbf{p H}$}

$\mathrm{pH}$ is an important indicator used to assess fish quality. Changes in $\mathrm{pH}$ value of cobia fillets dipped in extract solutions and the control during 15 days of storage are indicated in Table 3. At the day 10 and day 15 of storage, the fish flesh dipped with $P$. guajava extract showed a significant lower muscle
$\mathrm{pH}$ compared to the control $(\mathrm{p}<0.05)$. The $\mathrm{pH}$ values ranged 5.87 to 6.07 during ice storage. The muscle $\mathrm{pH}$ remained under 7 , showing that the products were not affected by the spoilage. The increase of $\mathrm{pH}$ caused by the increase of volatile basic compounds produced by either endogenous or microbial enzymes (Cann et al., 1983), and decomposition of nitrogenous components (Benjakul et al., 2002). In general, $\mathrm{pH}$ values did not show much variation during the entire period of storage, which was consistent with the yellow grouper ( $E p$ inephelus awoara) (Li et al., 2012) and the black sea bream (Sparus macrocephalus) (Feng et al., 2012).

Table 3. pH of cobia fillets of control and P. guajava soaking treatment, during ice storage

\begin{tabular}{lrrrr}
\hline \multirow{2}{*}{ Treatments } & \multicolumn{4}{c}{ Storage time (days) } \\
\cline { 2 - 5 } & $\mathbf{1}$ & $\mathbf{5}$ & $\mathbf{1 0}$ & $\mathbf{1 5}$ \\
\hline Control & $5.93 \pm 0.066$ & $5.87 \pm 0.033^{*}$ & $5.93 \pm 0.014^{*}$ & $6.07 \pm 0.063^{*}$ \\
$P$. guajava soaking & $5.88 \pm 0.030$ & $5.94 \pm 0.066^{*}$ & $5.86 \pm 0.026^{*}$ & $5.94 \pm 0.073^{*}$ \\
\hline
\end{tabular}

(*): shows statistically significant differences between the 2 treatments $(p<0.05)$ on the same days of sampling

\subsection{Water holding capacity}

Water holding capacity (WHC) is given as the amount of water retained after centrifugation in percent of the original total water in the sample. Changes in the water holding capacity values of cobia fillets during a period of 15 days are depicted in Figure 1. In general, the WHC values of samples treatment showed a gradually growing trend during storage time, ranged from 86.5 to $94.4 \%$. The increasing of WHC similar observations during ice storage of fish have been reported (Herland et al.,
2007; Digre et al., 2011). The increase in WHC was probably due to the growth of spoilage bacteria, the increase proteolytic activities leading degradation of protein, which contributes to the increased WHC (Olsson et al., 2003). No statistically significant differences were found for the WHC between the control and $P$. guajava soaking treatments at day 1,5 and 15 of storage time ( $\mathrm{p}>0.05)$. The results showed that soaking $P$. guajava did not significantly affect the WHC of fish fillets during the storage period.

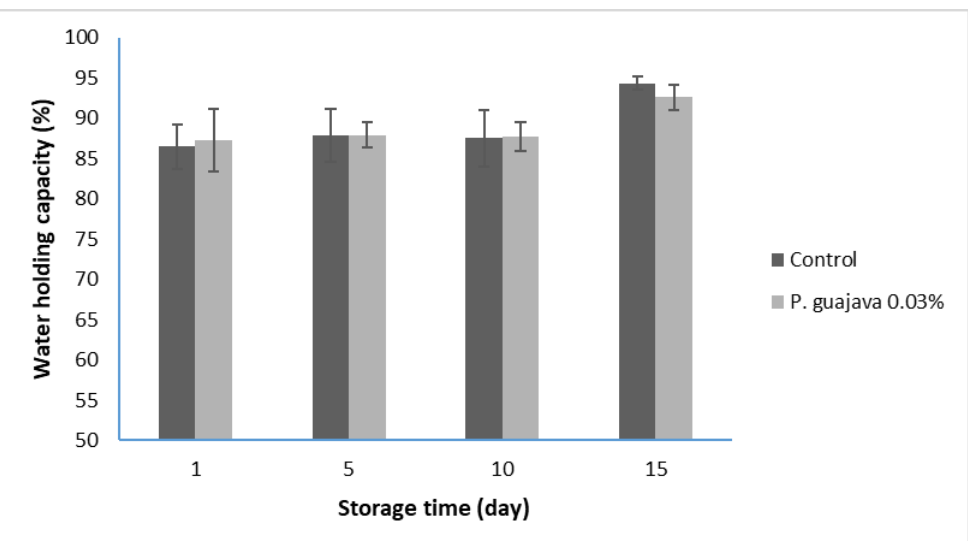

Figure 1. Water holding capacity of cobia fillets of control and P. guajava soaking treatments, during ice storage

\subsection{Moisture}

Changes in the moisture of cobia fillets during storage are presented in Table 4.
In general, the moisture content after 15 days of storage, from $74.1 \%$ to $71.3 \%$. The decrease in moisture content is due to dehydration of fish fillets. In the storage process, the amount of free wa- 
ter released and the associated water content in the fish are difficult to be broken along with the selfresolution. And denaturation of muscle protein causes the fish muscles became loose (Tsuchiya et al., 1992). No significant difference of moisture was observed between control and $P$. guajava soaking fillets during storage time $(\mathrm{p}>0.05)$. The present study indicated that soaking $P$. guajava before storage did not significantly impact the

Table 4. Moisture of cobia fillets of control and $P$. guajava soaking treatments, during ice storage

\begin{tabular}{lrrrr}
\hline \multirow{2}{*}{ Treatments } & \multicolumn{4}{c}{ Storage time (days) } \\
\cline { 2 - 5 } & $\mathbf{1}$ & $\mathbf{5}$ & $\mathbf{1 0}$ & $\mathbf{1 5}$ \\
\hline Control & $73.1 \pm 1.14$ & $73.0 \pm 0.94$ & $73.3 \pm 1.76$ & $71.8 \pm 1.59$ \\
P. guajava soaking & $74.1 \pm 1.53$ & $73.4 \pm 0.66$ & $73.2 \pm 0.84$ & $71.3 \pm 1.41$ \\
\hline
\end{tabular}

\subsection{Texture}

Texture of fish is one of the primary quality attributes for consumer acceptability (Di Monaco et al., 2008). In the present study, the texture of cobia fillets was determined by measuring the penetration strength. Changes in the penetration values of fish samples over iced storage period are illustrated in Figure 2.

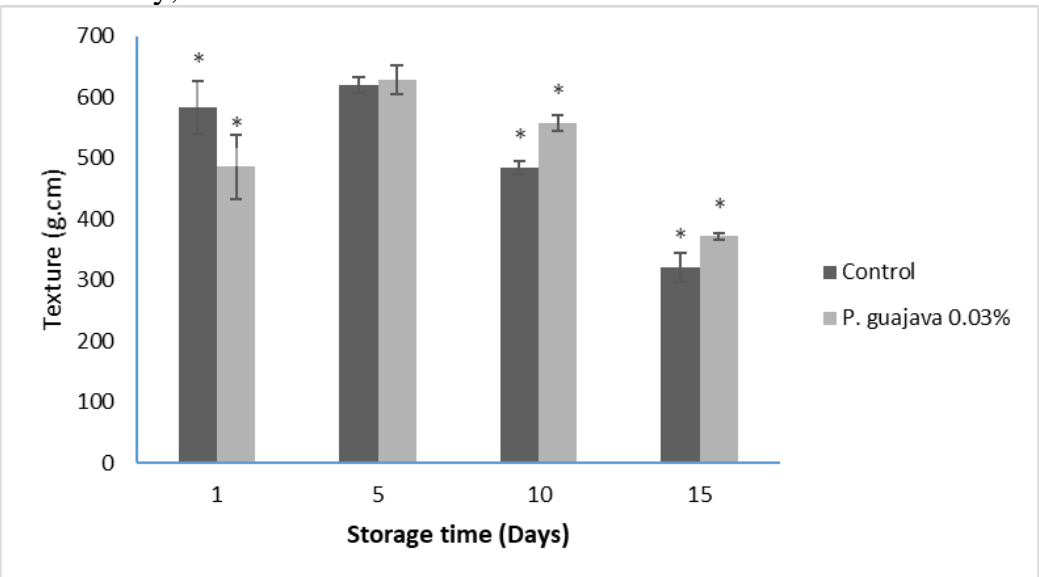

Figure 2. Penetration values (g.cm) of cobia fillets of control and P. guajava soaking treatments, during ice storage

(*): shows statistically significant differences between the 2 treatments $(p<0.05)$ on the same days of sampling

As seen in the Figure 2, significant difference of penetration values was observed between control and treated fish at day 1,10 and 15 of storage $(\mathrm{p}<0.05)$. Penetration values in both treatments tend to increase after 4 days of storage. Afterward, a slight decrease trend was seen over the storage period. The increase of firmness in fillets after 4 days of ice storage resulted from the stage of rigor mortis after the fish death. After 5 days of storage, the firmness decreased because of the activity of autolytic enzymes (e.g collagenase and ATPase) which degrade proteins from the connective tissue and the spoilage by bacteria (Lakshmanan et al., 2003). The hydrolysis and oxidation of proteins occurs over time, along with the self-degradation and denaturation of muscle proteins, thus, texture of cobia muscle become loose (Tsuchiya et al., 1992). Similar observations of texture softening during chilled storage of fish have been reported
(Jouki et al., 2014; Özyurt et al., 2015). Treated with $P$. guajava $0.03 \%$ reduced the fish muscle softening.

\subsection{Total volatile base nitrogen}

The TVB-N value is considered as an indicator of fish deterioration (Olafsdottir et al., 1997). Changes in the mean TVB-N values of cobia samples over iced storage period are depicted in the Table 5. Overall, TVB-N values of all fillet samples had a slightly growing trend from the beginning to the end of process storage (from 14.4 to $18.8 \mathrm{mgN} / 100$ g). At day 1 and day 5 of storage, the fish flesh dipped with $P$. guajava showed a significant lower ( $\mathrm{p}<0.05)$ compared to the control. However, no significant difference in TVB-N levels of in cobia fillets was observed between the control and soaking treatment from day 10 to day 15 of storage time ( $\mathrm{p}>0.05)$. The results showed that $P$. guajava soak- 
ing did not significantly affect the TVB-N of fillets during the storage period. This observation was in accordance with the result reported by Fogaça et al. (2017). In this research, TVB-N values were much

Table 5. Total volatile basic nitrogen (TVB-N; $\mathrm{mg} \mathrm{N} / 100 \mathrm{~g}$ ) of cobia fillets of control and $P$. guajava soaking treatments, during ice storage

\begin{tabular}{lrrrr}
\hline \multirow{2}{*}{ Treatments } & \multicolumn{4}{c}{ Storage time (days) } \\
\cline { 2 - 4 } & $\mathbf{1}$ & $\mathbf{5}$ & $\mathbf{1 0}$ & $\mathbf{1 5}$ \\
\hline Control & $16.3 \pm 0.14^{*}$ & $16.5 \pm 0.23^{*}$ & $17.3 \pm 0.14$ & $18.8 \pm 0.77$ \\
$P$. guajava soaking & $14.4 \pm 0.84^{*}$ & $14.9 \pm 0.53^{*}$ & $17.3 \pm 0.27$ & $18.0 \pm 0.42$ \\
\hline
\end{tabular}

$(*)$ : shows statistically significant differences between the 2 treatments $(p<0.05)$ on the same days of sampling

\subsection{Total viable count}

Changes of total viable bacteria count (TVC) of cobia fillets during the refrigerated storage were given in Figure 3.

The TVC values of three treatments increased gradually during the 15-day storage. The TVC in untreated fish fillets were significantly higher than in the $P$. guajava extract treated fish fillets at day 5 and 15 of storage $(\mathrm{p}<0.05)$. The fish samples of two treatments achieved TVC values higher than 7 $\log _{10} \mathrm{cfu} / \mathrm{g}$ on the day 15 of storage. Thus, a micro- lower than maximum acceptable limit of $35 \mathrm{mg}$ $\mathrm{N} / 100 \mathrm{~g}$ by Huss (1995) and smaller than 50 $\mathrm{mgN} / 100 \mathrm{~g}$ by Pike and Hardy (1997).

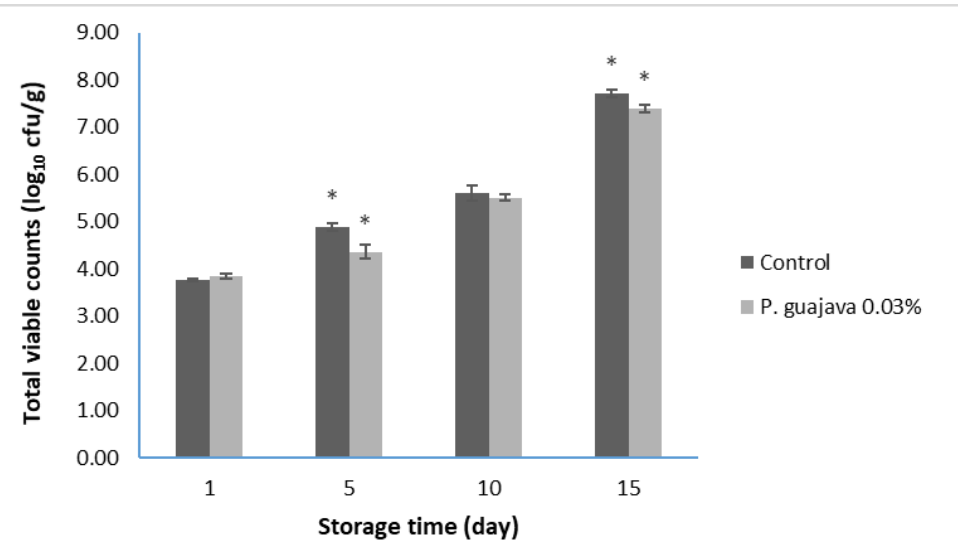

Figure 3. Total viable counts (TVC) of cobia fillets of control and P. guajava soaking treatments, during ice storage

(*): shows statistically significant differences between the 2 treatments $(p<0.05)$ on the same days of sampling

\subsection{Peroxide value}

The effect of dip treatment with $P$. guajava extract on changes in PV and TBARs of fish fillets are shown in Table 6.

The PV values of all treatments showed an increasing trend from day 1 to day 10 , then decrease at day 15 of storage time. This is in accordance with the result reported by Chaijan et al. (2006) on sardine (Sardinella gibbosa) muscle during iced storage, in which PV value increased until day 9 and then reduced until day 15 of storage. The decreased biological shelf-life was about 10 days for the cobia fillets during ice storage according to the microbiological acceptability limit value $(<6$ $\log _{10} \mathrm{cfu} / \mathrm{g}$ ) for raw fish of Vietnamese Ministry of Health (2012) and $\left(<7 \log _{10} \mathrm{CFU} / \mathrm{g}\right)$ for acceptable level TVC (ICMSF, 1986). In the present study, the results indicated that the use plant extract immersion exhibited the capacity in preventing the growth of bacteria during the initial storage period. The increase of TVC similar observations were reported by Cakli et al. (2007) in sea bream and sea bass refrigerated storage. 
duction of fatty acids free radicals and postpone the initiation of the autoxidative process in fat (Hraš et al., 2000). The phenolic content of the $P$. guajava extract was $14.5 \mathrm{mg}$ gallic acid equivalent/100 mg dry plant extract (Le Anh Dao et al., 2020). The present study indicated that soaking fillet with $P$. guajava before storage became delayed lipid peroxidation in cobia fillets during chilled storage.

Table 6. Peroxide value (PV; meq/kg) and Thiobarbituric acid reactive substances (TBARs; $\mathrm{mg}$ MDA $/ \mathrm{kg}$ ) of cobia fillets of control and $P$. guajava soaking treatments, during ice storage

\begin{tabular}{crrrr}
\hline \multirow{2}{*}{ Storage time (days) } & \multicolumn{2}{c}{ Peroxide value } & \multicolumn{2}{c}{ Thiobarbituric acid reactive } \\
\cline { 2 - 5 } & \multicolumn{1}{c}{ Control } & P. guajava soaking & \multicolumn{1}{c}{ Control } & \multicolumn{1}{c}{ P. guajava soaking } \\
\hline 1 & $2.78 \pm 0.94$ & $2.55 \pm 0.31$ & $0.53 \pm 0.04$ & $0.52 \pm 0.14$ \\
5 & $4.99 \pm 1.13^{*}$ & $2.73 \pm 0.58^{*}$ & $0.86 \pm 0.17^{*}$ & $0.36 \pm 0.08^{*}$ \\
10 & $5.53 \pm 1.17$ & $5.05 \pm 0.55$ & $0.89 \pm 0.08$ & $0.67 \pm 0.08$ \\
15 & $4.25 \pm 0.70^{*}$ & $3.11 \pm 0.93^{*}$ & $1.11 \pm 0.29$ & $0.81 \pm 0.39$ \\
\hline
\end{tabular}

(*): shows statistically significant differences between the 2 treatments $(p<0.05)$ on the same days of sampling

\subsection{Thiobarbituric acid reactive substances}

The effect of dip treatment with $P$. guajava extract on changes in TBARs of cobia fillets are presented in Table 5. In general, the TBARs values of all treatments showed an increasing trend during the 15-day storage. TBARs value of treatment soaking $P$. guajava was always lower than the control, but significant difference was only shown on day 5 of storage $(\mathrm{p}<0.05)$. A TBARs value in the range 5-8 $\mathrm{mg}$ malonaldehyde/ $\mathrm{kg}$ of fish sample is usually taken as the limit of acceptability (Sallam, 2007). Accordingly, TBA values in all the samples were within the acceptable limit throughout the storage period and lower than research of Rawdkuen et al. (2008). In the study of Feng et al. (2012), the lipid oxidation of black sea bream treated with tea polyphenol (TP and $\mathrm{TP}+\mathrm{O}_{3}$ treatment groups) showed the least effects than those of fish treated with $\mathrm{O}_{3}$ and the control. Haghparast et al. (2011) demonstrated that green tea extract and onion juice could delay effectively the peroxidation in Persian Sturgeon fillets and maintain the TBARs always lower than control sample. The results showed that soaking fillets with $P$. guajava extract delayed lipid peroxidation in cobia fillets during ice storage.

\subsection{Color measurements}

Color of fish fillet or products becomes important because it indicates the quality and is associated with freshness and flavor of the product. Changes in the instrumental color values of cobia fillet during chilled storage are depicted in Table 7.

Table 7. Color measurements of cobia fillets of control and $P$. guajava soaking treatments, during ice storage

\begin{tabular}{clrrr}
\hline Storage time (day) & Samples & $\mathbf{L}^{*}$ & $\mathbf{a}^{*}$ & $\mathbf{b}^{*}$ \\
\hline \multirow{2}{*}{1} & Control & $66.97 \pm 1.06$ & $-3.96 \pm 0.41^{*}$ & $3.98 \pm 0.90^{*}$ \\
& P. guajava soaking & $65.17 \pm 1.11$ & $-3.55 \pm 0.21^{*}$ & $2.53 \pm 0.23^{*}$ \\
\hline \multirow{2}{*}{5} & Control & $62.74 \pm 1.65$ & $-3.05 \pm 0.60$ & $4.16 \pm 1.68$ \\
& P. guajava soaking & $62.14 \pm 1.18$ & $-2.99 \pm 0.28$ & $3.29 \pm 0.79$ \\
\hline \multirow{2}{*}{10} & Control & $63.16 \pm 0.81^{*}$ & $-2.62 \pm 0.20^{*}$ & $5.89 \pm 0.83$ \\
& P. guajava soaking & $60.70 \pm 0.46^{*}$ & $-2.05 \pm 0.40^{*}$ & $5.40 \pm 0.53$ \\
\hline \multirow{2}{*}{15} & Control & $61.48 \pm 1.55$ & $-2.48 \pm 0.32^{*}$ & $6.30 \pm 0.31$ \\
& P. guajava soaking & $61.03 \pm 0.44$ & $-1.79 \pm 0.39^{*}$ & $6.72 \pm 0.91$ \\
\hline
\end{tabular}

(*): shows statistically significant differences between the 2 treatments $(p<0.05)$ on the same days of sampling

No significant difference of lightness $\left(\mathrm{L}^{*}\right)$ value was observed between control and plant extract treated fish fillets during storage time $(\mathrm{p}>0.05)$, apart day 10 . The decreasing trend in $\mathrm{L}^{*}$ value was observed in all the samples during storage while the redness $\left(a^{*}\right)$ and yellowness $\left(b^{*}\right)$ value showed gradually increased trend during storage time. The change of the color caused by the changes in the components of fish muscle such as lipid and protein oxidation, enzyme and microbial activity. Li- pid oxidation and breakdown of proteins form dark brown complexes, so, the light color of fish fillets decrease while yellow and red increase. The decreasing trend in $\mathrm{L}^{*}$ value was similar with the study of Mohan et al. (2012) in filleted Indian oil sardine by chilled storage.

\subsection{Sensory properties}

Sensory properties of food products are the key factors in consumer attraction (Gray et al., 1996). 
Results of total quality index (QI) of cobia fillets during 15 days of ice storage are presented in Figure 4. On the scale of QI used here, zero represented absolutely fresh fish and 14 defined a completely deteriorated fish. Generally, the scores of the sensory assessment exhibited a similar tendency of increasing for the flesh samples of all groups in all samples. During the remaining storage period, the fillets treated with plant extract exhibited a significant lower QI than the control samples in day 5 and $15(\mathrm{p}<0.05)$. The results show that fish fillets reacted with $P$. guajava extract shown less fishy smells and preferred by the panelists.

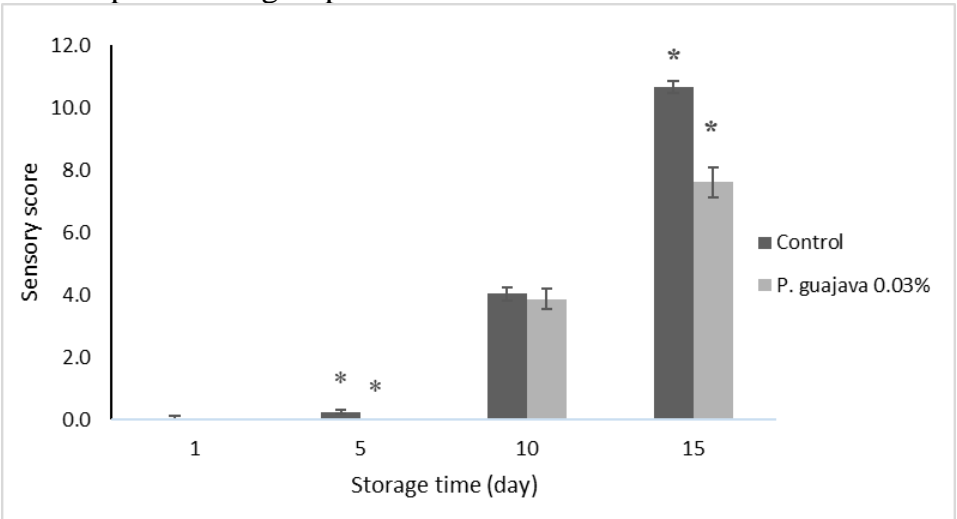

Figure 4. Quality index (QI) of cobia fillets of control and $P$. guajava soaking treatments, during ice storage

(*): shows statistically significant differences between the 2 treatments $(p<0.05)$ on the same days of sampling

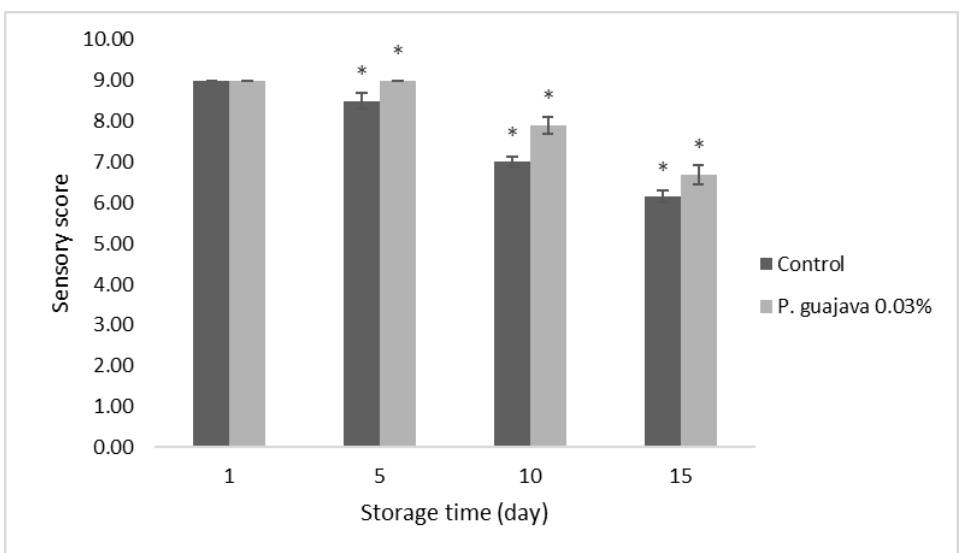

Figure 5. Taste of cooked cobia fillets of control and $P$. guajava soaking treatments, during ice storage

$(*)$ : shows statistically significant differences between the 2 treatments $(p<0.05)$ on the same days of sampling

Acceptability score for taste of cooked cobia fillets was evaluated by using nine-point scale. The fish samples were considered to be acceptable for human consumption until the sensory score reached 5 (Simeonidou, 1997). The scores of taste assessment of cooked fish are illustrated in Figure 5. The results indicated that sensory scores showed a similar pattern of decreasing acceptability for the flesh samples of the control and P. guajava extract treated with increasing storage period. The same result of sensory property was observed as fresh samples, the fillets treated with $P$. guajava extract was signif- icantly higher than the control samples $(\mathrm{p}<0.05)$, except day 1 . The control treatment displayed neutral taste and no off-flavors, but the present of $P$. guajava flavor improved the sensory property.

\section{CONCLUSIONS}

Treating cobia fillets in P. guajava extract solutions enhanced sensory property and firmness of cobia fillet during in ice storage. Based on the total viable count, it can be concluded that the cobia fillets in both treatments could be stored in ice for ten days. Moreover, P. guajava extract obviously in- 
hibited the formation of primary and secondary lipid oxidation and limited the growth of microorganisms in cobia fillets during iced storage.

\section{ACKNOWLEDGMENTS}

This study is funded by the Can Tho University Improvement Project VN14-P6, supported by Japanese ODA loan. The authors would like to send thanks to Thach Bao Toan, a student of Can Tho University for his support in this project.

\section{REFERENCES}

Arashisara, S., Hisara, O., Kayab, M., \& Yanik, T. (2004). Effects of modified atmosphere and vacuum packaging on microbiological and chemical properties of rainbow trout (Oncorynchus mykiss) fillets. International journal of food microbiology, 97(2), 209-214.

Babovic, N., Zizovic, I., Saicic, S., Ivanovic, J., \& Petrovic, S. (2010). Oxidative stabilization of Sunflower oil by antioxidant fractions from selected Lamiaceae herbs. Chemical Industry and Chemical Engineering Quarterly, 16(4), 287- 293.

Baldi, S. C. V., Parisi, G., Bonelli, A., Balieiro, J. C. C., Guimaraes, J. L., \& Viegas, E. M. M. (2018). Effects of different stunning/slaughter methods on frozen fillets quality of cobia (Rachycentron canadum). Aquaculture, 486, 107-113.

Benjakul, S., Visessanguan, W., Riebroy, S., Ishizaki, S., \& Tanaka, M. (2002). Gel-forming properties of surimi produced from bigeye snapper, Priacanthus tayenus and $P$ macracanthus, stored in ice. Journal of the Science of Food and Agriculture, 82(13), 1442-1451.

Cakli, S., Kilinc, B., Cadun, A., Dincer, T., \& Tolasa, S. (2007). Quality differences of whole ungutted sea bream (Sparus aurata) and sea bass (Dicentrarchus labrax) while stored in ice. Food Control, 18(5), 391-397.

Cann, D. L., Smith, G. L., \& Houston, N. G. (1983). Further Studies on Marine Fish Stored Under Modified Atmosphere Packaging. Aberdeen: Ministry of Agriculture Fisheries and Food, Torry Research Station. Scotland. 322p

Chaijan, M., Benjakul, S., Visessanguan, W., \& Faustman, C. (2006). Changes of lipids in sardine (Sardinella gibbosa) muscle during iced storage. Food Chemistry, 99(1), 83-91.

Chen, H. Y., \& Yen, G. C. (2007). Antioxidant activity and free radical-scavenging capacity of extracts from guava (Psidium guajava L.) leaves. Food chemistry. 101(2), 686-694.

Di Monaco, R., Cavella, S., \& Masi, P. (2008). Predicting sensory cohesiveness, hardness and springiness of solid foods from instrumental measurements. Journal of Texture Studies, 39(2), 129-149.
Erkan, N., Ulusoy, Ş., \& Tosun, Y. (2011). Effect of combined application of plant extract and vacuum packaged treatment on the quality of hot smoked rainbow trout. Journal für Verbraucherschutz und Lebensmittelsicherheit, 6(4), 419-426.

Falguera, V., Quintero, J. P., Jiménez, A., Muñoz, J. A., \& Ibarz, A. (2011). Edible films and coatings: Structures, active functions and trends in their use. Trends in Food Science \& Technology, 22(6), 292-303.

Fan, W. J., Chi, Y. L., \& Zhang, S. (2008). The use of a tea polyphenol dip to extend the shelf life of silver carp (Hypophthalmicthys molitrix) during storage in ice. Food Chemistry, 108(1), 148-153.

Feng, L., Jiang, T., Wang, Y., \& Li, J. (2012). Effects of tea polyphenol coating combined with ozone water washing on the storage quality of black sea bream (Sparus macrocephalus). Food chemistry, 135(4), 2915-2921.

Fogaça, F. H. D. S., Gonzaga Junior, M. A., Vieira, S. G. A., Araujo, T. D. S., Farias, E. A., Ferreira-Bravo, I. A., ... \& Prentice-Hernández, C. (2017). Appraising the shelf life of farmed cobia, Rachycentron canadum, by application of a Quality Index Method. Journal of the World Aquaculture Society, 48(1), 70-82.

Gonçalves, A. A., \& Santos, T. C. L. (2018). The effects of vacuum and modified atmosphere packaging on quality changes in seasoned cobia (Rachycentron canadum) sticks stored under refrigeration. Brazilian Journal of Food Technology, 21.

Gray, J. I., Gomaa, E. A., \& Buckley, D. J. (1996). Oxidative quality and shelf life of meats. Meat science. 43, 111-123.

Haghparast, S., Kashiri, H., Alipour, G., \& Shabanpour, B. (2011). Evaluation of Green Tea (Camellia sinenses) extract and onion (Allium cepa L.) juice effects on lipid degradation and sensory acceptance of Persian sturgeon (Acipenser persicus) fillets: a comparative study.

Herland, H., Esaiassen, M., \& Olsen, R. L. (2007). Muscle quality and storage stability of farmed cod ( $\mathrm{Ga}$ dus morhua L.) compared to wild cod. Journal of Aquatic Food Product Technology, 16(4), 55-66.

Hraš, A. R., Hadolin, M., Knez, Ž., \& Bauman, D. (2000). Comparison of antioxidative and synergistic effects of rosemary extract with $\alpha$-tocopherol, ascorbyl palmitate and citric acid in sunflower oil. Food chemistry, 71(2), 229-233.

Hultmann, L., Phu, T. M., Tobiassen, T., Aas-Hansen, Ø., \& Rustad, T. (2012). Effects of pre-slaughter stress on proteolytic enzyme activities and muscle quality of farmed Atlantic cod (Gadus morhua). Food chemistry, 134(3), 1399-1408.

Huss, H. H. (1995). Quality and quality changes in fresh fish, FAO Fisheries Technical Paper. No. 348. Rome.

ICMSF, 1986. Microorganisms in foods. 2. Sampling for microbiological analysis. Available from (2nd ed.). 
Toronto: University of Toronto Press. http://www.fao.org/DOCREP/003/T1768E/T1768E0 4.htm

Innis, S.M. (1991). Essential fatty acids in growth and development. Progress in Lipid Research. 30(1), 39-103.

International IDF Standards, 2006, Milk fatDetermination of peroxide value. International Dairy Federation, IDF-Square Vergote 41, Brussels, Belgium, IDF 74. https://www.sis.se/api/document/preview/907153/

Jouki, M., Mortazavi, S.A., Yazdi, F. T., Koocheki, A., \& Khazaei, N. (2014). Use of quince seed mucilage edible films containing natural preservatives to enhance physico-chemical quality of rainbow trout fillets during cold storage. Food Science and Human Wellness, 3(2), 65-72.

Kanner, J. (1994). Oxidative processes in meat and meat products: quality implications. Meat science, 36(12), 169-189..

Khanh, L. V., Phu, T. M., Dung, T. T., Hai, T. N. (2017). Current status of the common disease of cobia (Rachycentron canadum) and grouper (Epinephelus sp.) marine cage culture in Nam Du, Kiên Hải, Kiên Giang. Jounal of Marine Science and Technology, 17(1), 72-78 (in Vietnamese).

Lakshmanan, R., Piggott, J. R. \& Paterson, A. (2003). Potential applications of high pressure for improvement in salmon quality. Trends in Food Science and Technology, 14(9), 354-363.

Le Anh Dao, N., Phu, T. M., Douny, C., Quetin-Leclercq, J., Hue, B. T. B., Bach, L. T., ... \& Scippo, M. L. (2020). Screening and comparative study of in vitro antioxidant and antimicrobial activities of ethanolic extracts of selected Vietnamese plants. International Journal of Food Properties, 23(1), 481-496.

Li, T., Hu. W., Li, J., Zhang, X., Zhu, J., \& Li, X. (2012). Coating effects of tea pholyphenol and rosemary extract combined with chitosan on the storage quality of large yellow croaker (Pseudosciaena crocea). Food control. 25(1), 101-106.

Linhartová, Z., Lunda, R., Dvořák, P., Bárta, J., Bártová, V., Kadlec, J., ... \& Mráz, J. (2019). Influence of rosemary extract (Rosmarinus officinalis) Inolens to extend the shelf life of vacuum-packed rainbow trout (Oncorhynchus mykiss) fillets stored under refrigerated conditions. Aquaculture International, 27(3), 833-847.

Metwally, A. M., Omar, A. A., Harraz, F. M., \& EI Sohafy, S. M. (2010). Phytochemical investigation and antimicrobial activity of Psidium guajava $L$. leaves. Pharmacognosy magazine, 6(23), 212-218.

Mohan, C. O., Ravishankar, C. N., Lalitha, K. V., \& Gopal, T. S. (2012). Effect of chitosan edible coating on the quality of double filleted Indian oil sardine (Sardinella longiceps) during chilled storage. Food Hydrocolloids, 26(1), 167-174.
NKML, Nordic Committee on Food Analysis. (2006). Aerobic Plate Count in Food. Method No. 86.

Ofstad, R., Kidman, S., Myklebust, R., \& Hermansson, A. M. (1993). Liquid loss capacity and structural changes during heating of fish muscle: Cod (Gadus morhua L.) and salmon (Salmo salar). Food structure, 12(2), 4.

Olafsdottir, G., Martinsdóttir, E., Oehlenschläger, J., Dalgaard, P., Jensen, B., Undeland, I., Mackie, I. M., \& Nilsen, H. (1997). Methods to evaluate fish freshness in research and industry. Trends in food science \& technology, 8(8), 258-265.

Olsson, G. B., Ofstad, R., Lodemel, J. B., \& Olsen, R. L. (2003). Changes in water holding capacity of halibut muscle during cold storage. LWT-Food Science and Technology, 36(8), 771-778.

Özyurt, G., Özkütük, A. S., Şimşek, A., Yeşilsu, A. F., \& Ergüven, M. (2015). Quality and shelf life of cold and frozen rainbow trout (Oncorhynchus mykiss) fillets: Effects of fish protein-based biodegradable coatings. International Journal of Food Properties, 18(9), 1876-1887.

Pathare, P. B., Opara, U. L., \& Al-Said, F. A. J. (2013). Colour measurement and analysis in fresh and processed foods: a review. Food and bioprocess technology, 6(1), 36-60.

Pike, I. H., \& Hardy, R. W., 1997. Standards for assessing quality of feed ingredients. In: L. R. D’Abramo, D. M. Conklin, D. M. Akiyama, (Eds.), Crustacean Nutrition. Advances in World Aquaculture, vol. 6. World Aquaculture Society, Baton Rouge, LA. 473-491.

Raharjo, S., Sofos, J. N., \& Schmidt, G. R. (1992). Improved speed, specificity, and limit of determination of an aqueous acid extraction thiobarbituric acid-C18 method for measuring lipid peroxidation in beef. Journal of Agricultural and Food Chemistry, 40(11), 2182-2185.

Rawdkuen, S., Jongjareonrak, A., Benjakul, S., \& Chaijan, M. (2008). Discoloration and lipid deterioration of farmed giant catfish (Pangasianodon gigas) muscle during refrigerated storage. Journal of food science, 73(3), C179-C184.

Roberts, T. A., Cordier, J. L., Gram, L., Tompkin, R. B., Pitt, J. I., Gorris, L. G. M., \& Swanson, K. M. J. (Eds.). (2005). Micro-organisms in foods 6: microbial ecology of food commodities. London, UK: Springer US.

Robinson, J., Barnabas, E. R., \& Nathan, F. (2012). Quality changes of farmed cobia steaks held in cold stores $\left(-18^{\circ} \mathrm{C}\right)$. International Journal of Food Science and Technology, 47(11), 2429-2435.

Sallam, K. I. (2007). Antimicrobial and antioxidant effects of sodium acetate, sodium lactate, and sodium citrate in refrigerated sliced salmon. Food Control, $18(5), 566-575$. 
Schromuller, J. (1968). Handbuch der Lebensmittel Chemie, Band 11112 Teil. Tierische Lebensmittel Eier, Fleisch, Buttermilch.

Simeonidou, S., Govaris, A., \& Vareltzis, K. (1997). Effect of frozen storage on the quality of whole fish and fillets of horse mackerel (Trachurus trachurus) and Mediterranean hake (Merluccius mediterraneus). Zeitschrift für Lebensmitteluntersuchung und-Forschung A, 204(6), 405-410.

Sveinsdottir, K., Hyldig, G., Martinsdottir, E., Jorgensen, B., \& Kristbergsson, K. (2003). Quality Index Method (QIM) scheme developed for farmed Atlantic salmon (Salmo salar). Food Quality and Preference, 14(3), 237-245.

Taheri, S., Motallebi, A. A., Fazlara, A., Aghababyan, A., \& Aftabsavar, Y. (2012). Changes of fatty acid profiles in fillets of Cobia (Rachycentron canadum) during frozen storage. Iranian Journal of Fisheries Sciences, 11(1), 204-213.

Taheri, S., Motallebi, A.A., Fazlara, A., Aftabsavar, Y., \& Aubourg, S. P. (2012). Influence of vacuum packaging and long term storage on some quality parameters of cobia (Rachycentron canadum) fillets during frozen storage. American-Eurasian Journal of Agricultural and Environmental Sciences, 12(4), 541-547.

Tsuchiya, H., Kita, S., \& Seki, N. (1992). Postmortem changes in $\alpha$-actinin and connectin in carp and rainbow trout muscles. Nippon Suisan Gakkaishi, 58(4), 793-798.

Vanschoonbeek, K., de Maat, M. P., \& Heemskerk, J. W. (2003). Fish oil consumption and reduction of arterial disease. Journal of Nutrition, 133(3), 657-660.

VASEP, Vietnam Association of Seafood Exporters and Producers. (2018 October 14). Global tilapia production will be increased. http://vasep.com.vn/san-pham-xuat-khau/ca-tra/thitruong-the-gioi/san-luong-ca-ro-phi-toan-cau-dennam-2020-du-kien-tang-6969.html (in Vietnamese).

Velho, N. P. S. (2001). Preparation for obtaining accreditation of analytical methods regarding quality issues as stated in ISO standard ISO/IEC 17025:1999. Final project report.

Vietnamese Ministry of Health, 2012. National technical regulation of Microbiological contaminants in food (QCVN 8-3:2012/BYT). http://www.fsi.org.vn/vanban-phap-ly/1025_3002/qcvn-8-32012byt-quychuan-ky-thuat-quoc-gia-doi-voi-o-nhiem-vi-sinhvat-trong-thuc-pham.html (in Vietnamese). 